\title{
PERAN PEMERINTAH DALAM MENCEGAH TINDAKAN RADIKALISME MELALUI PENDIDIKAN MULTIKULTURAL
}

\author{
THE ROLE OF THE GOVERNMENT IN PREVENTING RADICALISM ACTIONS \\ THROUGH MULTICULTURAL EDUCATION
}

\author{
Eka Yanuarti \\ Institut Agama Islam Negeri Curup, Indonesia \\ Email: ekayanuarti@iaincurup.ac.id \\ Asri Karolina \\ Institut Agama Islam Negeri Curup, Indonesia \\ Email: asrikarolina@iaincurup.ac.id \\ Devi Purnama Sari \\ Institut Agama Islam Negeri Curup, Indonesia \\ Email: devipurnamasarihs@ gmail.com
}

\begin{abstract}
Abstrak
Penelitian ini bertujuan untuk mengetahui bagaimana peran pemerintah dalam mencegah tindakan radikalisme melalui penerapan pendidikan multikultura, penelitian ini menggunakan library reseach. Hasil penelitian ini menunjukkan bahwa ada 8 peran yang dapat diterapkan pemerintah dalam mencegah tindakan radikalisme melalui penerapan pendidikan multikultural yaitu pertama menawarkan berbagai kurikulum yang diterima dari masukan berbagai kalangan Kedua menyediakan berbagai fasiltas agar peserta didik mengetahui berbagai budaya, Ketiga memberikan pemahaman mengenai berbagai budaya, Keempat menyeleksi materi pembejaran yang menyebabkan munculnya tindakan radikalisme, Kelima menimalisir kesejangan sosial, Keenam menjaga kesatuan dan persatuan, Ketujuh mendukkung aksi perdamaian, Kedelapan ikut bersosialisasi dalam mencegah tindakan radikalisme
\end{abstract}

Kata Kunci: pemerintah, radikalisme, pendidikan multikultural

\begin{abstract}
This study aims to find out how the role of government in preventing acts of radicalism through the application of multicultural education, this study uses library research. The results of this study indicate that there are 8 roles that can be applied by the government in preventing acts of radicalism through the application of multicultural education, namely first offering various curricula received from input from various groups. Second, providing various facilities so that students know about various cultures, Third, providing understanding of various cultures, Fourth selecting material that causes the emergence of acts of radicalism, Fifth minimizing social equality, Sixth maintaining unity and unity, Seventh supporting peace actions, Eighth participate in socializing in preventing acts of radicalism.
\end{abstract}

Keywords: government, radicalism, multicultural education 


\section{A. Pendahuluan}

Indonesia adalah negara yang memiliki banyak adat-istiadat, suku, ras, agama, dan bahasa sehingga bisa dikatakan bahwa negara Indonesia ini adalah negera yang memiliki multikultural. Dengan banyak perbedaan baik dari segi adat-istiadat, suku, ras dan agama tentunya akan melahirkan banyak perbedaan pemikiran, sudut pandang hal inilah yang menyebabkan munculnya perselisihan dan munculnya suatu gerakkan seperti paham radikalisme.

Gerakan radikalisme ini adalah suatu pemikiran sekelompok masyarakat yang menghalalkan segala cara dalam mencapai sesuatu, penyebab gerakkan ini muncul dikarenakan persoalan agama, politik dan lainnya. Perbuatan radikalisme ini adalah perbuatan yang negatif. Karena dengan munculkan gerakkan radikalisme ini memiskinkan sikap demokrasi, dengan sikap demokrasi dapat menjadikan masyrakat yang harmonis, rukun dan toleransi.

Gerakan radikalisme seperi terorisme, GAM, OPM, RMS atau gerakkan pemberontak lainnya merupakan suatu tindakkan yang melanggar norma-norma agama maupun Pancasila. Gerakkan ini muncul dikarenakan pemikiran yang minim dari kelompok masyarakat sehingga menimbulkan kerugian yang besar bagi orang banyak.

Dalam mencegah munculnya gerakan radikalisme ini tentu tidak lepas dari perannya pemerintah. Karena pemerintah memiliki wewenang dalam mengeluarkan suatu keputusan atau kebijakkan terutama dalam hal ini yaitu gerakan radikalisme. Dalam hal ini adapun program pemerintah yang dianggap dapat menangani gerakan radikalisme yang meliputi program jangka pendek (menangulangi tindakan terorisme, menanamkan nilai-nilai Pancasila dilembaga pendidikan formal maupun nonformal mengadakan sosialisasi tentang pencegahan terorisme, mengenalkan dan memberikan pemahaman tentang anti terorisme) dan program jangka panjang (menanamkan pemahaman tentang sistem dan langkah-langkah dalam mencegah radikalisme, membuat perangkat nasional).

Ruslan Ibrahim pernah melakukan judul penelitian tentang upaya menimalisir konflik dalam era pluritas Agama, dalam penelitian ini menunjukkan bahwa dalam upaya menimalisir konflik dalam era pluritas agama yaitu dengan cara menerapkan 
pendidikan multikultural dalam kurikulum, dialog dari kelompok yang berbeda. ${ }^{1}$ Begitu juga penelitian yang dilakukan oleh Tatang $M$ Tamrin mengenai implementasi pendekatan pendidikan multikultural kontekstual berbasis kearifan lokal di Indonesia, yang menunjukkan bahwa implementasi pendidikan multikultural yaitu harus diutamakan papda pemahaman dan penghargaan peserta didik mengenai kemajmukan budaya di Indonesia dengan menanamkan nilai-nilai bhineka tunggal Ika. ${ }^{2}$ Mulyono Galih Fuji dan Mulyoto Galih Fuji juga pernah meneliti tentang radikalisme agama di Indonesia (ditinjau dari sudut pandang sosiologi kewarganegaraan), hasil penelitian ini menunjukkan bahwa radikalisme ini muncul dikarenakan adanya persoalan kesenjangan sosial, ekonomi dan politik serta kesenjangan ini juga muncul diakibatkan dari kegagalan negara Indonesia dalam memberikan keadilan sosial dan kesejahteraan seperti yang tertuang dalam UUD 1945.

\section{B. Metode Penelitian}

Penelitian ini menggunakan penelitian dengan pendekatan kualitatif dengan jenis penelitian kepustakaan. Kepustakaan atau library reseach ini adalah serangkaian kegiatan yang berkenaan dengan metode pengumpulan data pustaka, membaca dan mencatat serta mengolah bahan penelitian. Dalam penelitian ini penulis menggunakan personal document sebagai sumber data penelitian. Personal document adalah document pribadi yang berupa bahan-bahan tempat orang yang mengucapkan dengan kata-kata sendiri.

Dalam penelitian ini menggunakan teknik pengumpulan data dokumentasi yaitu dengan cara mengidentifikasi wacana dari buku-buku, artikel, jurnal dan internet yang berhubungan dengan peran pemerintah dalam mencegah tindakan radikalisme melalui pendidikan multikultural. Sebagaimana menurut Suharsimi Arikunto bahwa metode dokumentasi adalah mencari informasi mengenai suatu hal yang berupa catatan, transkip, buku, surat kabar, majalah dan sebagainya. ${ }^{3}$ Teknik analisis data yang digunakan dalam penelitian ini adalah sebagai berikut:

${ }^{1}$ Ruslan Ibrahim, "Pendidikan Multikultural: Upaya Meminimalisir Konflik Dalam Era Pluralitas Agama," El-Tarbawi, Vol. 1, No. 1 (2008): 115-127.

${ }^{2}$ Tatang M Amirin, "Implementasi Pendekatan Pendidikan Multikultural Kontekstual Berbasis Kearifan Lokal Di Indonesia," Jurnal Pembangunan Pendidikan: Fondasi Dan Aplikasi, Vol. 1, No. 1 (2012): 1-16

${ }^{3}$ Suharsimi Arikunto, Evaluasi Program Pendidikan (Jakarta: PT Bumi Aksara, 2008). 
a. Metode analisis deskriptif yaitu mengumpulkan data berupa kata-kata dan gambar yang kemudian digunakan untuk dianalisis.

b. Content anlysis atau analisis isi yaitu metodelogi yang memafaatkan seperangkat prosedur untuk menarik kesimpulan yang valid dari sebuah dokumen. Cara analisis isi ini dapat dilakukan dengan membandingkan antara buku satu dengan buku lain dalam bidang yang sama.

c. Analisis kritis yaitu pandangan yang menyatakan peneliti bukanlah subyek yang bebas nilai ketika memandang penelitian dan beranjak dari pandangan atau nilainilai tertentu yang diyakini peneliti.

\section{Hasil Penelitian dan Pembahasan}

\section{Pendidikan Multikultural}

Pendidikan memiliki peran penting dalam menentukan kemajuan suatu bangsa sejak zaman kemerdekaan hingga zaman setelah kemerdekaan, para pahlawan menyadari bahwa pendidikan merupakan sentral dalam usaha untuk membrantas kebodohan dan membebaskan dari penjajahan. ${ }^{4}$

Menurut Eka Yanuarti, arti dari pendidikan adalah usaha yang disengaja yang sistematis dan memiliki fungsi untuk mengembangkan potensi yang ada pada manusia agar digunakan secara optimal dan untuk menyempurnakan hidupnya dimasa yang akan datang. 5

Sedangkan multikultural adalah keberagaman budaya atau di dalam suatu kelompok atau bahkan negera memiliki budaya yang berbeda-beda. Sedangkan multikulturalisme diartikan sebagai kebudayaan. Kebudaaan memiliki fungsi sebagai pedoman bagi kehidupan manusia. ${ }^{6}$

Jadi dapat penulis simpulkan bahwa pendidikan multikultural adalah usaha yang disengaja secara sistematis yang digunakan untuk mengembangkan potensi yang ada pada manusia mengenai pemahaman mengenai keberagaman kebudayaan agar

${ }^{4}$ Eka Yanuarti, "PEMIKIRAN PENDIDIKAN KI. HAJAR DEWANTARA DAN RELEVANSINYA DENGAN KURIKULUM 13," JURNAL PENELITIAN, Vol. 11, No. 2, (2018): 237266.

${ }^{5}$ Eka Yanuarti, "Pendidikan Islam Dalam Perspektif Filsafat Idealisme," BELAJEA: Jurnal Pendidikan Islam, Vol. 1, No. 2 (2016): 145-166.

${ }^{6}$ Suharsono Suharsono, "Pendidikan Multikultural," EDUSIANA: Jurnal Manajemen Dan Pendidikan Islam, Vol. 4, No. 1 (2017): 13-23. 
terwujudlah kehidupan yang rukun dan damai dengan tetap menjaga keberagaman yang ada.

Pendidikan multikultural ini memiliki tujuan dalam pendidikan di antaranya yaitu $^{7}$ :

a. Mengembangkan literasi etnis dan budaya.

b. Memfasilitasi peserta didik bahwa semua budaya adalah sama, sehingga memunculkan kepercayaan diri setiap peserta didik untuk berinteraksi dengan orang lain.

c. Mengangkat nilai-nilai yang berasal dari prinsip martabat manusia, keadilan, persamaan dan demokratis.

d. Menciptakan persamaan kesempatan bagi setiap peserta didik tanpa memandang perbedaan yang ada.

e. Membantu siswa agar bisa memperoleh pengetahuan mencangkup semua ranah baik kognitif, afektif dan psikomotorik.

f. Memperoleh persamaan dan kualitas pendidikan.

g. Menjadikan para peserta didik sebagai agen perubahan sosial dalam membrantas diskriminasi atas perbedaan budaya.

h. Memiliki wawasan kebangsaan atau kenegaraan yang kokoh.

Pendidikan multikultural ini sangat penting untuk diterapkan adapun alasan pentingnya pendidikan multikultural adalah: ${ }^{8}$

a. Untuk memajukan ekonomi dengan perubahan kehidupan manusia

b. Mobilitas penduduk yang tinggi sehingga menyebabkan ada pertemuan yang sering antar kelompok dengan budaya yang berbeda.

c. Desa perdesaan semakin mudah untuk dijangkau.

d. Untuk memberikan pemahaman mengenai perbedaan budaya adalah kekuatan dan kekayaan yang dimiliki suatu negara dengan tetap menjaga persatuan.

e. Menghapus pendapat yang salah mengenai bahwa perbedaan adalah pemecah belah persatuan.

\footnotetext{
${ }^{7}$ Tatang M Amirin, "Implementasi Pendekatan..."

${ }^{8}$ R. Ibnu Ambarudin, "Pendidikan Multikultural Untuk Membangun Bangsa Yang Nasionalis Religius," Jurnal Civics: Media Kajian Kewarganegaraan, Vol. 13, No. 1 (2016): 28-45.
} 
Eka Yanuarti, Asri Karolina, Devi Purnama Sari: Peran Pemerintah dalam Mencegah Tindakan Radikalisme melalui Penerapan Pendidikan Multikultural

\section{Tindakan Radikalisme}

Radikal dalam bahasa Indonesia dapat diartikan suatu tindakan yang amat keras dalam menuntut perubahan. Sedangkan radikalisme merupakan paham yang menginginkan perubahan baik di bidang sosial maupun politik dengan cara kekerasan

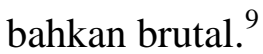

Radikalisme ditandai oleh 3 kecenderungan umum di antaranya yaitu:

a. Munculnya respon berupa evaluasi atau penolakan mengenai asumsi ide atau lembaga.

b. Berpendapat bahwa kebenaran hanya ideologi yang mereka bawa.

c. Menginginkan agar dunia ini dapat diubah sesuai dengan ajaran yang ia anut. $^{10}$

Adapun ciri-ciri dari orang yang menganut paham radikal di antaranya yaitu: ${ }^{11}$

a. Menganggap kebenaran hanya ada kelompok.

b. Mengangap ajaran Sunnah adalah wajib dan yang makruh menjadi haram.

c. Berlebihan dalam beragama dan pincangnya antara akhlak dan adab dengan ilmu yang ia miliki.

d. Keras dalam berdakwa

e. Selalu berburuk sangka kepada orang diluar kelompoknya

f. Mudah mengkafirkan orang lain.

Munculnya tindakan radikalisme ini tentunya ada latar belakang atau penyebabnya. Adapun faktor penyebab munculnya tindakan radikalisme yaitu: pertama, faktor pemikiran, kurangnya toleransi dan menerapkan ajaran agama secara taklid buta atau hanya sekedar meniru bukan dilandasi dengan syari'at yang benar. Kedua, faktor ekonomi, diiming-imingi uang ketika berhasil melaksanakan tugas dengan mengatasnamakan jihad. Ketiga, faktor sosial politik, memperkeruh keadaan dengan mengatasnamakan keadilan. ${ }^{12}$ Keempat, faktor psikologis, mengenai masalah perasaan berupa rasa cinta, rasa benci, dan dendam sehingga membuat seseorang melakukan

\footnotetext{
${ }^{9}$ Sun Choirol Ummah, “AKAR RADIKALISME ISLAM DI INDONESIA," Humanika, Kajian Ilmiah Mata Kuliah Umum, Vol. 12, No. 1 (2012): 112-124.

${ }^{10}$ Abdul Munip, "Menangkal Radikalisme Agama di Sekolah, "Jurnal Pendidikan Islam, Vol. 1, No. 2 (2012): 159-181.

${ }^{11}$ Ahdar Ahdar, "TINJAUAN KRITIS DAN MENYELURUH TERHADAP FUNDAMENTALISME DAN RADIKALISME ISLAM MASA KINI," KURIOSITAS: Media Komunikasi Sosial Dan Keagamaan, Vol. 10, No. 1 (2017): 582.

${ }^{12}$ Ahmad Asrori, "RADIKALISME DI INDONESIA: Antara Historisitas Dan Antropisitas," KALAM, Vol. 9, No. 2 (2017): 331.
} 
tindakan radikal. Kelima, faktor pendidikan, seorang tenaga pendidik yang memberikan pengetahuan atau pemahaman yang salah sehingga menimbulkan suatu tindakan yang radikal dalam diri peserta didik. Keenam, faktor keagamaan, munculnya paham beragama yang salah yang tidak sesuai dengan syari'at. Ketujuh, faktor kultural, belum siapnya masyarakat untuk menerima budaya dari luar sehingga menyebabkan adanya pembrontakan atau penolakan yang memunculkan tindakan radikal. Kedelapan, kebijakan pemerintah, ketidakmampuan pemerintah untuk memperbaiki situasi dan mencari akar permasalahan yang menyebabkan timbulnya tindakan radikal, sehingga tidak dapat mengatasi permasalahan sosial yang dihadapi umat. Selain itu ada juga faktor dari pers yang menyudutkan umat Islam munculnya tindakan radikal. Asumsiasumsi lewat pers memiliki kekuatan yang cukup berpengaruh sehingga tindakan radikal dianggap perbuatan dari umat Islam. ${ }^{13}$

\section{Peran Pemerintah dalam Mencegah Tindakan Radikalisme melalui Penerapan Pendidikan Multikultural}

Upaya pemerintah yang dapat diambil pemerintah dalam mencegah tindakan radikalisme melalui pendidikan, di antaranya yaitu:

a. Pemerataan Pendidikan

Setiap orang memiliki kesempatan yang sama dalam memperoleh pendidikan sesuai dengan UU No. 2 Tahun 1989 bahwa sistem pendidikan Nasional tidak dibedakan menurut jenis kelamin, status sosial, ekonomi, agama dan lokasi geografis. ${ }^{14}$

Dalam rangka mewujudkan pemerataan pendidikan tentunya harus ada peran pemerintah di antaranya yaitu ${ }^{15}$ :

1) Program Pendidikan Dasar dan Prasekolah

Pemerataan jangkauan prasekolah yaitu dengan cara meningkatkan partisipasi masyarakat dalam menyediakan lembaga TPA, kelompok bermain dan TK yang bermutu dengan memberikan kemudahan, bantuan dan penghargaan oleh pemerintah.

Kegiatan utama dalam mengupayakan pendidikan dasar di antaranya, yaitu pertama, meningkatkan fasilitas mengenai sarana dan prasarana pendidikan. Kedua,

\footnotetext{
${ }^{13}$ Andik Wahyun Muqoyyidin, "Membangun Kesadaran Inklusifmultikultural Untuk Deradikalisasi Pendidikan Islam," Jurnal Pendidikan Islam, Vol. 2, No. 1 (2013): 131-151.

${ }^{14}$ Mujahidin, "Pemerataan Pendidikan Anak Bangsa Pendidikan Kapatalisme Pendidikan," Pemerataan Pendidikan Anak Bangsa, 2016.

${ }^{15}$ Muhammad Idrus, "MUTU PENDIDIKAN DAN PEMERATAAN PENDIDIKAN DI DAERAH," PSIKOPEDAGOGIA Jurnal Bimbingan Dan Konseling, Vol. 1, No. 2 (2012).
} 
memberikan subsidi kepada sekolah agar bisa mewujudkan sekolah yang berkualitas. Ketiga, memberikan layanan pendidikan bagi masyarakat yang kurang mampu terasing, minoritas dan sekolah didesa terpencil. Keempat, melaksanakan revitalisasi. Kelima, memberikan beasiswa berprestasi atau keluarga kurang mampu. Keenam, memberikan dana pendidikan untuk keberlangsungan pendidikan.

2) Program Pendidikan Menengah

Upaya yang dapat dilakukan untuk pemerataan di pendidikan menengah di antaranya, yaitu: pertama membangun sarana sekolah yang memadai; kedua, memberikan layanan pendidikan bagi masyarakat kurang beruntung; ketiga, memberikan beasiswa bagi siswa yang berprestasi atau kurang mampu.

3) Program Pendidikan Tinggi

Upaya yang dapat dilakukan agar pemerataan program pendidikan tinggi di antaranya, yaitu: pertama meningkan daya tambung dalam setiap prodi agar dapat menunjang kemajuan ekonomi dan meningkatkan kualitas SDM; kedua, peningkatan peran swasta melalui perguruan tinggi swasta; ketiga, meningkatkan penyediaan beasiswa bagi mahasiswa kurang mampu dan berprestasi.

Dalam penyebaran kapasitas pendidikan secara geografis akan mendukung pembangunan daerah dan dapat membantu masyarakat yang berpenghasilan rendah.

b. Peningkatan relevansi pendidikan dengan kebutuhan pembangunan

Peningkatan relevansi pendidikan ini dapat dilakukan secara pemerataan kesempatan, kualitas, efisiensi.

c. Peningkatan kualitas pendidikan nasional

Kegiatan utama yang dapat dilakukan agar peningkatan kualitas pendidikan nasional dapat terwujud dapat lakukan dengan cara: pertama, meningkatan kemampuan akademisi dan meningkatkan kesejahteraan para pendidik agar pendidik dapat berfungsi secara optimal; kedua, melakukan pembaharuan sistem pendidikan; ketiga, memberdayakan lembaga pendidikan baik yang formal maupun non formal; keempat, melakukan pembaharuan berdasarkan prinsip desentralisasi, otonomi keilmuan dan manajemen; kelima, meningkatkan kualitas lembaga pendidikan; keenam, mengembangkan SDM secara terarah, terpadu dan komprehensif; ketujuh, meningkatkan penguasaan, pengembangan dan pemanfaatan TIK; kedelapan, 
mengembangkan program internationalization; kesembilan, melaksanakan program kemitraan agar lulusan perguruan tinggi dapat terjun kedunia kerja.

d. Peningkatan efisiensi pendidikan

Peningkatan efisiensi pendidikan yaitu jika hasil yang dicapai maksimal dan biaya yang dikeluarkan sesuai dengan kebutuhan.

e. Pembangunan pendidikan nasional dalam menunjang kualitas SDM

Kesejahteraan suatu negara tidak hanya dinilai dari kekayaan alam saya namun juga dinilai dari kualitas SDM, dengan adanya pendidikan nasional dalam membantu peningkatan kualitas SDM agar dapat memanfaatkan kekayaan sumber daya alam yang ada. $^{16}$

Adapun upaya pemerintah dalam mencegah tindakan radikalisme melalui pendidikan multikultural di sekolah yaitu sebagai berikut: ${ }^{17}$

a. Menjadikan pendidikan multikultural sebagai pengembang kurikulum

Dalam pencegahan tindakan radikalisme pendidikan multikultural adalah pendidikan yang dapat menanamkan nilai-nilai multikultarisme agar manusia bisa hidup rukun dan damai walaupun memiliki keberagaman mulai dari perbedaan kultural, agama, dan bahasa agar bangsa Indonesia memiliki kekuatan.

Dalam mengembangkan kurikulum yang menggunakan pendekatan pendidikan kurikulum harus memiliki empat prinsip yaitu penentuan filsafat, keberagaman budaya sebagai dasar dalam mengembangkan berbagai komponen kurikulum, menjadikan sumber belajar dan objek belajar sebagai budaya di lingkungan unit pendidikan, kurikulum dijadikan sbegai media dalam mengembangkan dan mempertahankan kebudayaan.

b. Menjadikan pendidikan multikultural sebagai solusi ancaman keberagaman

c. Menjadikan pendidikan multikultural sebagai penanaman moral

Dalam menanamkan moral terutama mengenai sikap toleransi menghargai keberagaman yang ada yaitu dengan pendidikan multikultural.

\footnotetext{
${ }^{16}$ Puspo Dewi Dirgantari, "Pengaruh Kualitas Layanan Jasa Pendidikan terhadap Kepuasan Mahasiswa serta Dampaknya terhadap Upaya Peningkatan Citra Perguruan Tinggi Negeri Menuju World Class University (Studi pada Mahasiswa Asing Di ITB, UNPAD, Dan UPI)," JURNAL ILMU MANAJEMEN DAN BISNIS, Vol. 3, No. 2 (2012).

${ }^{17}$ Heri Cahyono and Iswati Iswati, "URGENSI PENDIDIKAN MULTIKULTURAL SEBAGAI UPAYA MENINGKATKAN APRESIASI SISWA TERHADAP KEARIFAN BUDAYA LOKAL," Elementary: Jurnal Ilmiah Pendidikan Dasar, Vol. 3, No. 1 (2017): 15-29
} 
Upaya dalam mencegah tindakan radikalisme melalui pendidikan multikultural di luar sekolah yaitu dapat dilakukan dengan cara sebagai berikut:

a. Memberikan wawasan ilmu pengetahuan yang benar

Memperkenalkan ilmu pengetahuan yang benar mengenai pencegahan tindakan radikalisme kepada siapapun terutama genarasi muda, hal ini dikarenakan gerenasi muda memiliki rasa keingintahuan yang kuat terutama mengenai hal yang baru. Dalam hal ini memberikan ilmu pengetahuan bukanlah hanya memberikan pengetahuan yang umum saja juga memberikan ilmu pengetahuan yang benar mengenai ilmu agama yang sesuai dengan syari'at agar semangat beragama generasi muda terarah.

b. Memberikan pemahaman mengenai Ilmu pengetahuan yang benar

Setelah memberikan wawasan ilmu pengetahuan yang benar kita harus memberikan pemahaman mengenai ilmu pengetahuan yang benar tersebut, agar ilmu pengetahuan yang benar ini tidak hanya teori belaka tetapi juga dapat diterapkan, terutama dalam mencegah tindakan radikalisme sehingga keutuhan NKRI dapat terjaga.

c. Menimalisir kesenjangan sosial

Pemerintah harus dapat meminalisir kesenjangan sosial yang ada dalam masyarakat agar munculnya pemahaman radikalisme dapat dicegah, kesenjangan antara pemerintah dan rakyat ini dapat diminalisir dengan cara pemerintah merangkul pihak media yang menjadi perantara dengan rakyat dan melakukan aksi nyata kepada rakyat, begitu juga sebaliknya rakyat harus selalu memberikan dukungan dan kepercayaan kepada pemerintah agar pemerintah dapat menjalankan tugasnya dengan maksimal. ${ }^{18}$

d. Menjaga persatuan dan kesatuan

Dalam mencegah pemahaman radikalisme kita bersama haruslah menjaga persatuan dan kesatuan, didalam sebuah masyarakat tentunya tidak lepas dari kebaragaman terlebih lagi sebuah negara yang terdiri dari gabungan masyarakat tentunya akan banyak sekali keberagaman dalam menjaga persatuan dan kesatuan kita harus memahami dan menjalankan nilai-nilai yang tekandung dalam Pancasila terutama mengenai semboyan Bhineka Tunggal Ika.

e. Mendukung aksi perdamaian

Mencegah tindakan radikalisme atau tindakan terorisme dapat dilakukan dengan aksi perdamaian sebagai usaha agar tindakan tersebut dapat dicegah atau dihentikan, aksi perdamaian ini dapat dilakukan oleh organisasi ataupun perseorangan.

${ }^{18}$ Juju Masunah, "Konsep Dan Praktik Pendidikan Multikultural di Amerika Serikat dan Indonesia," Jurnal Ilmu Pendidikan, Vol. 17, No. 4 (2011): 298-306. 
f. Berperan aktif dalam melaporkan tindakan radikalisme

Peranan yang dapat dilakukan dalam mencegah tindakan radikalisme ini yaitu dengan cara melaporkan kepada pihak yang berwewenang apabila megetahui munculnya radikalisme atau terorisme baik dalam skala kecil maupun besar. Tentunya sebelum melaporkan kita harus mengetahui ciri-ciri yang tergolong radikalisme. ${ }^{19}$

g. Meningkatkan pemahaman akan hidup kebersamaan

Dengan meningkatkan pemahaman bahwa manusia memerlukan manusia lain dan tidak mungkin sekian banyak manusia di dunia ini memiliki karakter yang sama, agama yang sama, suku dan budaya yang sama justru dengan keberagaman yang ada akan menjadi kekayaan dan saling melengkapi kekurangan.

h. Menyaring informasi yang didapatkan

Mengingat tidak semua informasi yang didapatkan adalah benar, maka dari itu kita harus cerdas dalam memilah dan memilih informasi agar tidak mudah terpengaruh dengan provokator-provokator yang ingin menciptakan perpecahan antar umat beragama dan agar keutuhan NKRI dapat terjaga. ${ }^{20}$

Dalam mencegah tindakan radikalisme melalui pendidikan multikultural tentunya tidak lepas dari perannya pemerintah agar pendidikan multikultural ini dapat diterapkan, adapun peran pemerintah dalam mencegah tindakan radikalisme melalui pendidikan multikultural baik disekolah maupun diluar sekolah, di antaranya yaitu:

a. Menawarkan keberagaman kurikulum dengan melibatkan dari berbagai kalangan tidak hanya mengambil keputuhan datu kebijakan berdasarkan dari salah satu pihak saja harus mempertimbangkan dari segala aspek untuk kepentingan bersama.

b. Menyediakan fasilitas kepada peserta didik agar peserta didik mengetahui dan memahami berbagai budaya hal ini diperlukan dalam mengembangkan literasi etnis dan budaya tanpa membeda-bedakan dari ras, suku maupun agama.

c. Memberikan pemahaman mengenai bahwa semua budaya setiap etnis memiliki kesempatan yang sama dalam memperoleh pendidikan tanpa mebeda-bedakan,

${ }^{19}$ Abdul Rohman and Yenni Eria Ningsih, "Pendidikan Multikultural: Penguatan Identitas Nasional di Era Revolusi Industri 4.0," Prosiding, Seminar Nasional Multidisiplin, UNWAHA Jombang, (2018): 44-50.

${ }^{20}$ Lilam Kadarin Nuriyanto, "Bimbingan Konseling Melalui Pendidikan Multikultural terhadap Anak-Anak dan Remaja dalam Penanggulangan Paham Radikalisme," Konseling Religi: Jurnal Bimbingan Konseling Islam, Vol. 5, No. 1 (2014): 19-40. 
sehingga peserta didik memiliki kepercayaan diri untuk berinteraksi dengan orang lain yang berbeda budaya, agama, ras dan agama dengannya hal ini dibutuhkan untuk perkembangan pribadi.

d. Pemerintah dapat mengambil dengan kebijakan setiap konten isi pembelajaran harus diseleksi terlebih dahulu, agar terhindar dari materi-materi yang bersifat intoleran sehingga dapat melahirkan jiwa-jiwa jihad yang salah yang menyebabkan munculnya tidakan radikalisme.

e. Menimalisir kesejangan sosial, pemerintah harus dapat meminalisir kesenjangan sosial yang ada dalam masyarakat agar munculnya pemahaman radikalisme dapat dicegah, kesenjangan antara pemerintah dan rakyat ini dapat diminalisir dengan cara pemerintah merangkul pihak media yang menjadi perantara dengan rakyat dan melakukan aksi nyata kepada rakyat, begitu juga sebaliknya rakyat harus selalu memberikan dukungan dan kepercayaan kepada pemerintah agar pemerintah dapat menjalankan tugasnya dengan maksimal.

f. Menjaga persatuan dan kesatuan, menjaga persatuan dan kesatuan, dalam mencegah pemahaman radikalisme sebenarnya tidak hanya peran pemerintah saja tetapi juga peran masyarakat, dalam hal ini pemerintah lebih memiliki peran dan wewenang dan tugas dalam menjaga persatuan dan kesatuan agar dapat ditiru oleh rakyat biasa, di dalam sebuah masyarakat tentunya tidak lepas dari kebaragaman terlebih lagi sebuah negara yang terdiri dari gabungan masyarakat tentunya akan banyak sekali keberagaman dalam menjaga persatuan dan kesatuan harus memahami dan menjalankan nilai-nilai yang tekandung dalam Pancasila terutama mengenai semboyan Bhineka Tunggal Ika.

g. Mendukung aksi perdamaian, mencegah tindakan radikalisme atau tindakan terorisme dapat dilakukan dengan aksi perdamaian sebagai usaha agar tindakan tersebut dapat dicegah atau dihentikan, aksi perdamaian ini dapat dilakukan oleh organisasi ataupun perseorangan..

h. Ikut aktif dalam mensosialiasikan pencegahan radikalisme, mensosialisasi di sini maksudnya memberikan pemahaman kepada masyarakat mengenai tindakan radikalisme dan dampak yang ditimbulkan akibat dari tindakan radikalisme. 


\section{Kesimpulan}

Dari pembahasan di atas dapat disimpulkan bahwa ada delapan peran yang dapat dilakukan pemerintah dalam mencegah tindakan radikalisme melalui penerapan pendidikan multicultural, yaitu: pertama, menawarkan berbagai kurikulum yang diterima dari masukan berbagai kalangan; kedua, menyediakan berbagai fasiltas agar peserta didik mengetahui berbagai buday; ketiga, memberikan pemahaman mengenai berbagai budaya; keempat, menyeleksi materi pembejaran yang menyebabkan munculnya tindakan radikalisme; kelima, menimalisir kesejangan social; keenam menjaga kesatuan dan persatuan; ketujuh mendukkung aksi perdamaian; dan kedelapan, ikut bersosialisasi dalam mencegah tindakan radikalisme.

\section{E. Daftar Pustaka}

Ahdar. "TINJAUAN KRITIS DAN MENYELURUH TERHADAP FUNDAMENTALISME DAN RADIKALISME ISLAM MASA KINI," KURIOSITAS: Media Komunikasi Sosial Dan Keagamaan, Vol. 10, No. 1 (2017): 582.

Ambarudin, R. Ibnu, "Pendidikan Multikultural untuk Membangun Bangsa yang Nasionalis Religius." Jurnal Civics: Media Kajian Kewarganegaraan, Vol. 13, No. 1 (2016): 28-45.

Arikunto, Suharsimi. Evaluasi Program Pendidikan. Jakarta: PT Bumi Aksara, 2008.

Asrori, Ahmad. "RADIKALISME DI INDONESIA: Antara Historisitas Dan Antropisitas." KALAM, Vol. 9, No. 2 (2017): 331.

Cahyono, Heri dan Iswati. "URGENSI PENDIDIKAN MULTIKULTURAL SEBAGAI UPAYA MENINGKATKAN APRESIASI SISWA TERHADAP KEARIFAN BUDAYA LOKAL." Elementary: Jurnal Ilmiah Pendidikan Dasar, Vol. 3, No. 1 (2017): 15-29

Dirgantari, Puspo Dewi. "Pengaruh Kualitas Layanan Jasa Pendidikan terhadap Kepuasan Mahasiswa serta Dampaknya terhadap Upaya Peningkatan Citra Perguruan Tinggi Negeri Menuju World Class University (Studi pada Mahasiswa Asing Di ITB, UNPAD, Dan UPI)." JURNAL ILMU MANAJEMEN DAN BISNIS, Vol. 3, No. 2 (2012).

Ibrahim, Ruslan. "Pendidikan Multikultural: Upaya Meminimalisir Konflik Dalam Era Pluralitas Agama." El-Tarbawi, Vol. 1, No. 1 (2008), 115-127.

Idrus, Muhammad. "MUTU PENDIDIKAN DAN PEMERATAAN PENDIDIKAN DI DAERAH." PSIKOPEDAGOGIA Jurnal Bimbingan Dan Konseling, Vol. 1, No. 2 (2012).

M Amirin, Tatang. "Implementasi Pendekatan Pendidikan Multikultural Kontekstual Berbasis Kearifan Lokal Di Indonesia." Jurnal Pembangunan Pendidikan: Fondasi Dan Aplikasi, Vol. 1, No. 1 (2012): 1-16. 
Eka Yanuarti, Asri Karolina, Devi Purnama Sari: Peran Pemerintah dalam Mencegah Tindakan Radikalisme melalui Penerapan Pendidikan Multikultural

Masunah, Juju. "Konsep dan Praktik Pendidikan Multikultural di Amerika Serikat dan Indonesia." Jurnal Ilmu Pendidikan, Vol. 17, No. 4 (2011): 298-306.

Mujahidin. "Pemerataan Pendidikan Anak Bangsa Pendidikan Kapatalisme Pendidikan." Pemerataan Pendidikan Anak Bangsa, 2016.

Munip, Abdul. "Menangkal Radikalisme Agama Di Sekolah." Jurnal Pendidikan Islam, Vol. 1, No. 2 (2012): 159-181.

Muqoyyidin, Andik Wahyun. "Membangun Kesadaran Inklusifmultikultural Untuk Deradikalisasi Pendidikan Islam." Jurnal Pendidikan Islam, Vol. 2, No. 1 (2013): 131-151.

Nuriyanto, Lilam Kadarin. "Bimbingan Konseling Melalui Pendidikan Multikultural terhadap Anak-Anak dan Remaja dalam Penanggulangan Paham Radikalisme." Konseling Religi: Jurnal Bimbingan Konseling Islam, Vol. 5, No. 1 (2014): 1940.

Rohman, Abdul dan Yenni Eria Ningsih, "Pendidikan Multikultural: Penguatan Identitas Nasional di Era Revolusi Industri 4.0," Prosiding, Seminar Nasional Multidisiplin, UNWAHA Jombang, (2018): 44-50.

Suharsono. "Pendidikan Multikultural." EDUSIANA: Jurnal Manajemen Dan Pendidikan Islam, Vol. 4, No. 1 (2017): 13-23.

Ummah, Sun Choirol. "AKAR RADIKALISME ISLAM DI INDONESIA." Humanika, Kajian Ilmiah Mata Kuliah Umum, Vol. 12, No. 1 (2012): 112-124.

Yanuarti, Eka. "PEMIKIRAN PENDIDIKAN KI. HAJAR DEWANTARA DAN RELEVANSINYA DENGAN KURIKULUM 13." JURNAL PENELITIAN, Vol. 11, No. 2, (2018), 237-266.

Yanuarti, Eka. "Pendidikan Islam Dalam Perspektif Filsafat Idealisme." BELAJEA: Jurnal Pendidikan Islam, Vol. 1, No. 2 (2016): 145-166. 